\title{
THE COMPOSITION OF HUMAN MILK AS A MODEL FOR THE DESIGN OF INFANT FORMULAS: RECENT FINDINGS AND POSSIBLE APPLICATIONS
}

\author{
ANNEMIEK C. GOEDHART AND JACQUES G. BINDELS \\ Nutricia Research, P.O. Box 1, 2700 MA Zoetermeer, The Netherlands
}

\section{CONTENTS}

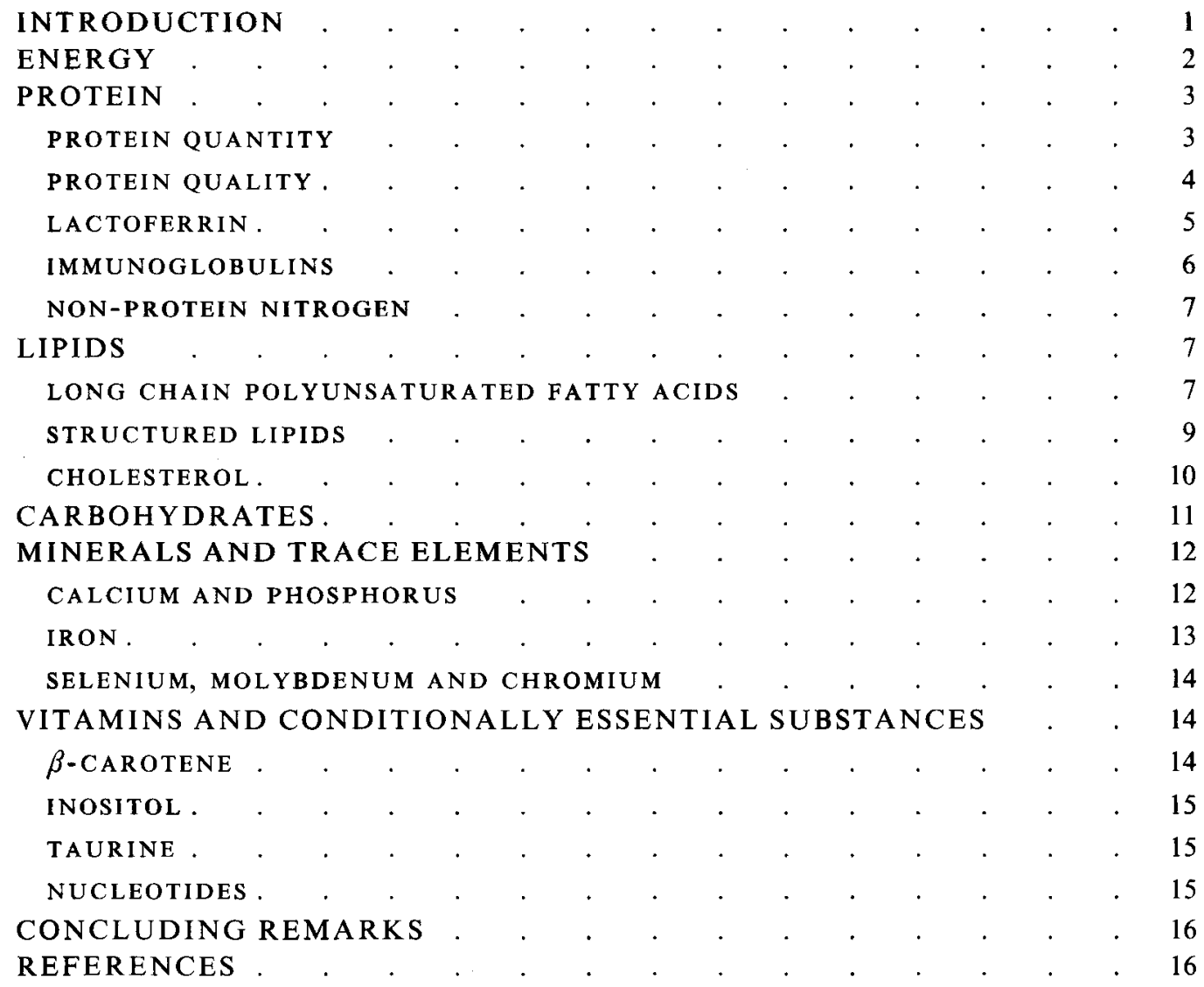

\section{INTRODUCTION}

Human milk is assumed to be the ideal food for the infant at least up to the age of 5 or 6 months, ensuring optimal growth and development (ESPGAN, 1982). In many respects human milk, the most natural food available, is unique. The nutritional composition of 
human milk varies from mother to mother, from day to day, during the day and even during a feed, and is generally suited to the individual needs of the infant. There is little doubt that human milk serves a role in infant physiology greater than being a supply of energy and nutrients. For instance, the immunological properties of human milk (immunoglobulins, bacteriostatic proteins, living cells, antiviral lipids) are well documented. In developing countries these established beneficial properties can be translated into demonstrable advantages to the breast fed over the bottle fed infant, in terms of reduced morbidity and mortality (Jason et al. 1984; Hanson et al. 1994). Controversy persists, however, about whether breast feeding protects infants in Western countries from infectious diseases and, if so, the magnitude of this effect. Four of the five epidemiological studies in industrialized countries published between 1970 and 1984 that met the methodological standards set by Bauchner et al. (1986) concluded that breast feeding was not protective against infections. Only one of the studies did show a protective effect of breast feeding against gastrointestinal infections among infants younger than four months. Newer studies continue to suggest only a minimal protective effect of breast feeding in industrialized countries, with the clearest impact on gastroenteritis (Wright et al. 1989; Howie et al. 1990; Rubin et al. 1990).

While human milk is superior for the newborn infant, milk substitutes play a necessary role in infant nutrition when breast feeding is not possible, desirable or sufficient. The search for human milk substitutes has been conducted since the Stone Age, but it was not until sanitation practices developed in the late nineteenth century that feeding these substitutes, mostly based on cows' milk, to infants could be safely accomplished. Since then, there have been progressive attempts to bring the composition of these formulations closer to human milk. Important modifications included reduction of the protein and electrolyte content, addition of vitamins, trace elements and lactose, alteration of the casein: whey protein ratio, and substitution of unsaturated vegetable fats for butterfat. With the addition of taurine some years ago a new phase in the development of infant formulas has commenced. Presently, research is concentrating on those substances in human milk which serve other than traditional nutritional roles. Attempts are in progress to supplement infant formulas with protective and trophic factors so far unique only to human milk. The final aim is not necessarily to mimic the composition of human milk in every respect, but to achieve physiological effects as in breast fed infants.

In this paper, the relevant aspects of the composition of human milk and of the current infant formulas will be reviewed, and an outline of some of the expected developments in the composition of infant formulas will be given.

\section{ENERGY}

The energy requirements of infants reflect levels of energy intake that will promote health, adequate growth, optimal body composition, and levels of physical áctivity appropriate for their developmental age. The average energy density of mature human milk is generally used as a basis for the assessment of the infant's energy requirement, and thus as a guideline for the energy content of infant formulas.

Traditionally, the energy density of human milk has been assessed by analysis of its macronutrient composition, obtained by manual or mechanical expression from the breast. To calculate the energy density of the milk from its macronutrient composition, the standard Atwater conversion factors are used. The mean energy value of mature milk obtained by this method is around $700 \mathrm{kcal} / 1$ (Department of Health and Social Security, 1977). This method of estimating energy density is subject to error, however, as milk that 
has been obtained by whole breast expression may not be identical in composition to suckled milk. In particular, the fat content, a major determinant of energy content, may be higher in expressed milk, which may result in an overestimation of the energy density of suckled milk (Lucas et al. 1990). Another potential problem of this method of estimating energy density is that the Atwater factors used to estimate metabolizable energy from macronutrient composition may be inappropriate for young infants, as nutrient absorption may be less than that accounted for in these conversion factors. The recent development of the doubly labelled water method for determining energy expenditure, energy stored in new tissue, and water (and therefore milk) intake has made it possible to estimate the energy density of suckled breast milk. Using this method, the metabolizable energy content of breast milk has been found to be $530 \mathrm{kcal} / 1$ and $580 \mathrm{kcal} / 1$ at 6 weeks and 3 months of age respectively (Lucas et al. 1990). The metabolizable energy values obtained for infants fed formula with a calculated energy density of $680 \mathrm{kcal} / 1$ at these ages were 600 and $660 \mathrm{kcal} / 1$ respectively, suggesting that the use of the Atwater factors may indeed lead to an overestimation of the metabolizable energy intake in the first weeks of life.

These data have important potential consequences for infant nutrition. It may be that current guidelines for energy intake in infancy are too high and thus need revision (Prentice et al. 1988). This may explain why breast fed infants grow less rapidly than formula fed infants, despite their lower total daily energy expenditure (Butte et al. 1990; Heinig et al. 1993).

Further research is needed to confirm the energy values for suckled milk found by Lucas et al. (1990), and to determine whether the energy density of infant formulas should be lowered towards these values.

\section{PROTEIN}

\section{PROTEIN QUANTITY}

It is now generally accepted that the true protein content of mature milk is only about 8-10 g/l and that the earlier overestimation was due to a large proportion of nitrogen that is not part of human milk protein (Hambraeus et al. 1978; Räihä, 1985; Harzer et al. 1986). This so-called non-protein nitrogen fraction includes about $20-25 \%$ in human milk (Hambraeus et al. 1978; Harzer et al. 1986).

Since some of the protective whey proteins of human milk, particularly secretory IgA and lactoferrin, are quite resistant to low $\mathrm{pH}$ and the action of proteolytic enzymes and are to a significant extent excreted in the infant's stools, the nutritionally available protein of mature human milk may be as low as 6-8 g/l (Räihä, 1985; Davidson \& Lönnerdal, 1987).

Through the last decades, there has been a trend towards lowering the protein levels of infant formulas, in order to make them more similar to human milk. A major reason for this decrease has been the finding that formula fed infants have elevated plasma concentrations of urea and of specific amino acids, which suggests that these infants may be exposed to unnecessary metabolic stress (Järvenpää et al. 1982a, b; Janas et al. 1985). Several studies evaluated the effects of lowering the protein content of formula to values of $11-13 \mathrm{~g} / \mathrm{l}$, while varying the casein: whey protein ratio (Räihä et al. 1986a, b; Picone et al. 1989; Lönnerdal \& Chen, 1990). Infants receiving such a low protein formula had growth rates and indices of protein nutritional status similar to those of breast fed infants. During the first four weeks of life, however, Räihä et al. $(1986 a, b)$ observed that the infants fed the low protein formula $(12.5 \mathrm{~g} / 1)$ had blood urea nitrogen and urine nitrogen concentrations that were significantly lower than those of the breast fed group. The fact that this finding could not be confirmed by other investigators, even when a formula with a protein level of as low as $11 \mathrm{~g} / \mathrm{l}$ was given, may at least be partly explained by differences 
in non-protein nitrogen levels between the formulas used (Donovan \& Lönnerdal, 1989). In none of the studies could plasma amino acid patterns identical to those of breast fed infants be produced, suggesting that factors other than the amino acid pattern of human milk influence plasma amino acid levels (Picone et al. 1989). Reducing the protein content of formula to values of around $13 \mathrm{~g} / \mathrm{l}$ has been observed to result in low plasma tryptophan values relative to those of breast fed infants, presumably owing to inadequate intake and reduced bioavailability of tryptophan from bovine whey protein (Janas et al. 1987). Low plasma tryptophan levels may be of concern as tryptophan is an essential amino acid and a precursor of serotonin and niacin. Addition of free tryptophan to a low protein formula has been found to result in plasma tryptophan levels similar to those of breast fed infants, and to influence the infants' sleep latency (Hanning et al. 1992; Fazzolari-Nesci et al. 1992; Steinberg et al. 1992).

\section{PROTEIN QUALITY}

The concentration of whey proteins in human milk decreases from early lactation and continues to fall. These changes result in a casein: whey protein ratio of about 10:90 in the first days of lactation and of about 45:55 in mature milk (Harzer et al. 1986; Kunz \& Lönnerdal, 1992). The optimal casein : whey protein ratio of infant formulas is still a point of controversy. Growth rates do not differ between infants fed whey predominant formulas and those receiving casein predominant formulas (Harrison et al. 1987; Janas et al. 1987; Lönnerdal \& Chen, 1990). Theoretically, whey predominant formulas may offer some minor advantages for newborns because they form a finer, softer curd than casein predominant formulas leading to higher gastric emptying rates, which are more comparable to those of breast fed infants (Nakai \& Li-Chan, 1987; Billeaud et al. 1990). Further, during the first two months a whey predominant formula was found to induce a faecal flora somewhat closer to that of breast fed babies than a casein predominant formula (Balmer et al. 1989). It should be noted, however, that the casein predominant formula used in this study had higher protein and phosphate contents than the whey predominant one, and therefore presumably a higher buffering capacity. The functional consequences of the observed differences in gastric emptying and intestinal flora still have to be demonstrated. The same holds true for the putative advantages of casein predominant formula being more satisfying or less allergenic.

Since there is no convincing evidence that whey predominant formulas are superior in composition or physiological effect, the Scientific Committee for Food, set up by the European Communities, recommended in their opinion expressed on 17 September 1993 not to adhere any longer to different minimal values for the protein content of infant formula dependent on the casein:whey protein ratio.

Human milk casein and its subunits represent the least understood and characterized class of proteins in human milk. Important differences exist between human and bovine caseins. $\beta$-Casein is the predominant casein in human milk, whereas cows' milk contains a large proportion of $\alpha$-caseins (Eigel et al. 1984; Kunz \& Lönnerdal, 1990). Additionally, physicochemical differences between human and bovine caseins affect curd formation, which in turn influences gastric emptying and intestinal transit time (Nakai \& Li-Chan, 1987; Billeaud et al. 1990). Partial enzymic dephosphorylation and/or rennet modification may improve coagulation characteristics and digestibility of bovine caseins for infant feeding (Nakai \& Li-Chan, 1987; Li-Chan \& Nakai, 1989). The physiological roles of casein in mineral absorption and in providing fragments with immunomodulating and opioid-like activities need further study (Migliore-Samour \& Jollès, 1988; Daniel et al. 1990). 


\section{LACTOFERRIN}

Of the protective whey proteins in human milk, the iron binding glycoprotein lactoferrin is the second most abundant one, being present in colostrum and mature milk in concentrations of about 5-7 and 1-2 g/1 respectively (Hambraeus et al. 1978; Goldman et al. 1982). Lactoferrin is remarkably resistant to degradation by proteinases (Davidson \& Lönnerdal, 1987).

The possible physiological functions of lactoferrin have recently been reviewed by Iyer \& Lönnerdal (1993). Lactoferrin has been suggested to have bacteriostatic activity, to enhance iron absorption, and to stimulate mucosal proliferation. The bacteriostatic and bactericidal effects of lactoferrin in vitro have been studied in a wide range of microorganisms. Lactoferrin withholds iron from invading organisms by its high iron affinity as well as its slow rate of change to a conformation in which the iron site is exposed (Chung \& Raymond, 1993). Next to iron withholding, other mechanisms may be involved in the antibacterial action of lactoferrin, and a synergic mechanism with lysozyme and/or IgG has been proposed (Iyer \& Lönnerdal, 1993). Convincing in vivo data which confirm the in vitro findings are still lacking. Limited hydrolysis of bovine lactoferrin resulted in potent antibacterial activity, suggesting that lactoferrin latently contains at least one antibacterial peptide region that is released when the molecule is hydrolysed. The bactericidal activity of the peptide fragments did not have any relation to iron chelation (Saito et al. 1991). The putative bactericidal domain, lactoferricin, has recently been isolated and described in bovine and human lactoferrin. The region is distinct from the iron binding region. The antimicrobial peptide of bovine lactoferrin was found to be more active than that of human lactoferrin (Bellamy et al. 1992). Further studies are required to determine whether digestion of either human or bovine lactoferrin in vivo generates potent bactericidal peptides in sufficient quantities to be of biological importance for neonates.

The precise role of lactoferrin in iron absorption has not yet been defined. Clinical trials in which infant formulas were supplemented with bovine lactoferrin have failed to demonstrate an improvement in iron absorption (Fairweather-Tait et al. 1987; Schulz-Lell et al. 1991). Possible explanations for these negative results are (1) the species specificity of the human lactoferrin receptor (if this receptor is involved in iron transport), and (2) inappropriateness of the composition of the formulas used (high in citrate and phosphate, low in bicarbonate). Chierici et al. (1992) reported, however, that infants fed a lactoferrin supplemented formula had higher ferritin levels than those fed the control formula, and not significantly different from the breast fed group. Both the experimental and the control formulas contained no added iron. One possible flaw of this study was the fact that the lactoferrin supplemented formula contained more endogenous iron than the nonsupplemented control formula. Recently, Davidsson et al. (1994) surprisingly observed that iron absorption in infants was significantly lower from human milk with its native content of lactoferrin than from lactoferrin free human milk, which suggests that human milk lactoferrin may have no direct role in the enhancement of iron absorption. More studies are needed to define the role of lactoferrin in iron transport better. Lactoferrin could well be involved in iron metabolism, acting as a regulator of iron absorption when iron stores are adequate and as an enhancer of iron absorption in deficiency states (Iyer \& Lönnerdal, 1993).

The hypothesis that lactoferrin acts as a growth factor for the intestine remains to be confirmed in vivo (Nichols et al. 1987; Iyer \& Lönnerdal, 1993).

In the coming years, it will be possible to perform in vivo supplementation trials using human lactoferrin produced in the mammary glands of transgenic dairy animals. Transgenic dairy calves have already been generated carrying the human lactoferrin fusion 
gene (Krimpenfort, 1993). It is hoped that these studies will lead to a better understanding of the biological functions of human milk lactoferrin.

\section{IMMUNOGLOBULINS}

Secretory IgA comprises over $90 \%$ of the immunoglobulins in human milk. The highest concentrations of $\operatorname{sigA}(\sim 9 \mathrm{~g} / 1)$ are found in colostrum. Mature milk has sIgA levels averaging 1-2 g/l (Harzer \& Bindels, 1985; Goldman \& Goldblum, 1989). Human milk sIgA is directed against enteric and respiratory immunogens that have triggered the maternal enterobronchial mammary gland pathways (Goldman \& Goldblum, 1989). Secretory IgA antibodies in human milk neutralize bacterial toxins and virulence factors and inhibit adherence and proliferation of bacteria on epithelial surfaces by binding to the bacterial adhesins (Goldman \& Goldblum, 1989; Davin et al. 1991).

In order to improve the immunological composition of infant formulas, in theory IgA derived from human milk or produced through genetic engineering should be used. It is extremely difficult, however, to harvest large amounts of $\operatorname{IgA}$ from human milk for commercial purposes. Additionally, large scale production of sIgA by recombinant DNA technology may be a daunting task since the molecule has four different types of peptide chains, the formation of antigen combining sites requires the rearrangement of four different groups of genes, once the relevant peptides are produced it would be necessary to link them, and many different antibodies would be required to create a broad range of specificities (Goldman, 1989).

As a more feasible alternative to human $\operatorname{IgA}$, bovine antibodies could be used. Whereas sIgA is the predominant class of immunoglobulins in human milk, $\operatorname{IgG}_{1}$ is predominant in cows' milk. Even though it is structurally different, it appears to have the same function (Facon et al. 1993). Attempts have been made to increase the immunoglobulin concentration of cows' milk and to manipulate its specificity by immunization. In several studies infants were prophylactically supplemented with immunoglobulins isolated from the milk of cows immunized to specific pathogens. Davidson et al. (1989) demonstrated that bovine colostrum with high antibody titre against four human rotavirus serotypes, given as a supplement, was highly effective in protecting hospitalized infants against rotavirus infection. Additionally, administration of colostrum from rotavirus immunized cows prevented rotavirus infections in infants living in an orphanage (Ebina et al. 1985). Turner \& Kelsey (1991) reported that administration of bovine milk antibodies to human rotavirus did reduce rotavirus associated illness but not rotavirus infection. Brunser et al. (1992) failed to prevent rotavirus and Escherichia coli infections in infants living in low socioeconomic conditions by providing a formula containing bovine milk antibodies against these pathogens. The investigators postulated that the dose of immunoglobulin given may have been too low and/or the age of the infants (majority 9-12 months) may have had an influence on the digestive enzymes and thereby on the unprotected passage of the antibodies through the intestine.

Larger scale controlled clinical trials are needed to prove the efficacy of passive oral immunization with milk antibodies from immunized cows, to ascertain whether the risks of such antibody supplementation are minimal, and to determine the minimal effective dose (Goldman, 1989; Boesman-Finkelstein \& Finkelstein, 1991). It is not inconceivable that in the future immunoglobulin fortified infant formulas will be developed, which can be given to non-breast fed infants susceptible to infections by intestinal pathogens, such as those that are immunodeficient (Shield et al. 1993) and/or those in contaminated environments such as hospitals (Goldman, 1989; Facon et al. 1993). 


\section{NON-PROTEIN NITROGEN}

Many non-protein nitrogen components have been identified, including urea, uric acid, ammonia, creatine and creatinine, free amino acids, nucleic acids and nucleotides, polyamines, carnitine, low molecular weight peptide hormones, growth factors, the amino sugars $N$-acetylglucosamine and $N$-acetylneuraminic acid (sialic acid), and the amino alcohols choline and ethanolamine (Carlson, 1985a; Atkinson et al. 1989). Some of this nitrogen contributes to the pool available for synthesis of non-essential amino acids. For instance urea nitrogen, which accounts for 30-50\% of the non-protein nitrogen fraction, is partly hydrolysed to ammonia by intestinal microorganisms, with subsequent intestinal absorption of the released ammonia. From studies with isotopically labelled urea, it has been estimated that about $13-23 \%$ of dietary urea is retained and available for amino acid synthesis (Heine et al. 1986; Fomon et al. 1988).

Other non-protein nitrogen compounds may be involved in the development of the newborn infant. Taurine and nucleotides have been claimed to be conditionally essential substances and are dealt with later. Non-protein nitrogen components with clear trophic characteristics are polyamines (spermine, spermidine, putrescine) and epidermal growth factor. Polyamines are known to be involved in cell proliferation and differentiation in many tissues, including the gastrointestinal tract (Pegg, 1986; Pollack et al. 1992). Whereas human milk has been found to contain considerable amounts of putrescine, spermine, and spermidine, standard cows' milk based infant formulas contain no detectable polyamines or only very small amounts (Pollack et al. 1992; Romain et al. 1992). Additionally, epidermal growth factor may be involved in maturational processes of the newborn (Kidwell \& Salomon, 1989). It can be expected that this rapidly emerging research area will give us significant information with regard to the importance of human milk for gut proliferation and maturation.

\section{LIPIDS}

\section{LONG CHAIN POLYUNSATURATED FATTY ACIDS}

Fats are vital for normal growth and development. In addition to providing energy, fats supply essential fatty acids and are the vehicle for fat-soluble vitamins and hormones in milk. Recently, the essential fatty acid requirements of newborns have received increasing attention. Particular interest has focused on the importance of long chain polyunsaturated fatty acids with 20 and 22 carbon atoms (LCP). These fatty acids are important structural components of cell membrane phospholipids, particularly those of the central nervous system and of retinal photoreceptors, and serve as precursors for the synthesis of eicosanoids (British Nutrition Foundation, 1992).

Docosahexaenoic acid (DHA) and arachidonic acid (AA) constitute a large proportion of the total lipids in brain and retina and their accretion primarily occurs during the last trimester of pregnancy and the first year of life (Clandinin et al. 1980a,b). Fetal accretion of LCP may result from placental transfer (Kuhn \& Crawford, 1986). Postnatally, human milk provides the breast fed infant with preformed AA and DHA. Term human milk has an AA content of about $0.5 \%$ and a DHA content of about $0.3 \%$ of total fatty acids (Koletzko et al. 1992). The mean LCP levels of colostrum and preterm milk are higher (Rönneberg \& Skåra, 1992; Foreman-van Drongelen et al. 1994).

The available evidence strongly suggests that a dietary supply of LCP is desirable for the preterm infant. Preterm infants fed formulas without LCP develop poor AA and DHA status, suggesting that the preterm infant is unable sufficiently to elongate and desaturate linoleic acid and $\alpha$-linolenic acid to their long chain derivatives (Carlson et al. 1991). The 
DHA status of preterm infants is positively related to their visual acuity, whereas their AA status positively correlates with their first-year growth and with scores on development tests (Carlson et al. 1992a, 1993a,b). Feeding formulas supplemented with fish oil to preterm infants improves their DHA status and visual function (Carlson et al. 1991, 1993 b; Birch et al. 1992) but their AA status deteriorates and may result in poorer growth (Carlson et al. 1991, 1992b).

Both the ESPGAN Committee on Nutrition (1991) and the British Nutrition Foundation (1992) recommend enrichment of premature formulas with AA and DHA. There are already some premature formulas available which are supplemented with DHA and either AA or its precursor, the $\delta-6$ desaturation product $\gamma$-linolenic acid. In term infants, however, supplementation of $\gamma$-linolenic acid was not able to prevent the fall in AA, which suggests that it may not be sufficient simply to bypass the first $\delta-6$ desaturation step (Makrides et al. 1993a).

It is to be expected that within the next few years all premature formulas will contain both preformed DHA and AA. In the absence of a clear understanding of the actual LCP requirements of preterm infants, it seems prudent to aim at LCP levels at least approximating to those of preterm human milk, as the most important period for brain AA and DHA accumulation is the third trimester of gestation, and as the preterm infant is exposed to a significantly reduced intake of LCP compared to what it would have obtained by placental transfer had it been born at term.

The degree to which a dietary source of preformed LCP is also essential for term infants is an area of active investigation. As in preterm infants, the levels of AA and DHA in plasma and erythrocyte phospholipids of term, formula fed infants are lower than of breast fed infants (Clark et al. 1992; Makrides et al. 1993a,b). Decreasing the linoleic acid: $\alpha$ linolenic acid ratio of a term formula to about 4:1 improves the DHA status of the infants, although not to values as in breast fed infants, but it worsens their AA status (Clark et al. 1992). Recently it has been demonstrated that breast fed infants have higher DHA concentrations in their brain cortical phospholipids, and higher AA and DHA concentrations in subcutaneous tissue, compared to infants fed formula (Farquharson et al. 1992, 1993).

The observed differences in LCP levels of brain cortex and subcutaneous tissue between breast fed and formula fed infants may affect physiological function. Term, breast fed infants have been found to have a better visual function (visual evoked potential acuity) at four to five months of age than infants fed a formula devoid of LCP (Birch et al. 1992; Makrides et al. 1993 b). Additionally, at 3 years of age, breast fed infants have been found to have a significantly better visual function (stereo acuity and letter matching ability) than infants fed a corn oil formula during the first year of life (Uauy et al. 1992; Birch et al. 1993). The scores on the tests of visual function at 3 years were correlated with the DHA status at 4 months of life. It should be noted, however, that the formula used in this study was deficient in $\alpha$-linolenic acid. Supplementing infant formula with fish oil and evening primrose oil (containing $\gamma$-linolenic acid) improved the DHA status and visual acuity of term infants. AA levels of these infants were reduced below levels of infants fed the non-supplemented formula, which did not, however, negatively affect growth (Makrides et al. 1993a).

The British Nutrition Foundation (1992) recommends that infant formulas should contain AA and DHA in amounts similar to those of human milk, although the Task Force acknowledges that addition of these LCP is of most importance for preterm formulas. Farquharson et al. $(1992,1993)$ concluded from their studies that a minimum daily requirement of $0.2 \mathrm{~g} \mathrm{DHA} / 100 \mathrm{~g}$ fatty acids (or $30 \mathrm{mg} \mathrm{DHA} / \mathrm{d}$ ) should be supplied in formulas designed for term infants to prevent the cerebrocortical deficiency of DHA. In 
their most recent opinion, expressed on 17 September 1993, the Scientific Committee for Food stated not to object to the possibility of adding them in infant formulas provided that the resulting content in n-3 and n-6 LCP is similar to that present in human milk in Europe, and that the eicosapentaenoic acid content does not exceed that of DHA.

It is as yet unknown whether the effect of dietary DHA on neural maturity is long lasting. Longer term effects of lower concentrations of DHA in cerebrocortical phospholipids on neuronal integrity and function need urgent study (Cockburn, 1994). However, the fact that mature human milk contains both AA and DHA in considerable amounts may already serve as a rationale to add AA and DHA to term infant formulas, provided the amounts do not exceed those of human milk.

\section{STRUCTURED LIPIDS}

Another topical issue with respect to infant formula fat is the development of structured triacylglycerols. The fatty acids in human milk triacylglycerols have a highly specific positional distribution (Martin et al. 1993). Especially the positional distribution of palmitic acid in human milk has received increasing attention. Palmitic acid constitutes about $22 \%$ of mature human milk lipids and $70-75 \%$ of it is esterified at the sn- 2 position ( $\beta$-position) of the triacylglycerol (Freeman et al. 1965; Christie, 1986; Martin et al. 1993). The palmitic acid in vegetable oils commonly used in infant formulas and in chicken egg, on the other hand, is predominantly esterified at the sn-1 and sn-3 positions (Freeman et al. 1965; Tomarelli et al. 1968; Christie, 1986). Pancreatic colipase dependent lipase selectively hydrolyses the fatty acids at the sn- 1 and sn- 3 positions, yielding free fatty acids and a 2-monoacylglycerol (Bernbäck et al. 1990). The 2-monoacylglycerol is a well absorbed form of most fatty acids since it readily forms micelles with bile acids and cannot form insoluble soaps with cations like calcium and magnesium. Therefore, the absorption of palmitic acid is likely to be greater when it is esterified at the sn-2 position than when it is attached predominantly at the sn-1,3 positions (Small, 1991). Indeed, mixtures of coconut oil and palm olein are better absorbed by rats if the proportions of palmitic and stearic acids in the sn-2 position are increased by chemical randomization (Lien et al. 1993).

Several studies have focused on the effect of the triacylglycerol configuration on intestinal fat absorption in preterm infants (Brooke 1985; Verkade et al. 1989). Carnielli et al. (1994) recently evaluated the effects of two formulas for preterm infants, differing only in the isomeric position of palmitic acid, on the absorption of fat and fatty acids and on mineral balance in a crossover study in preterm infants. The palmitic acid content of both formulas was $25-26 \%$ of total fatty acids. Although total fat absorption was not significantly different between the two groups, infants who were given the formula with palmitic acid predominantly esterified at the sn- 2 position showed a significantly higher palmitic acid absorption compared with the infants that obtained the control formula with palmitic acid mainly attached to the sn-1,3 positions. This effect on palmitic acid strongly correlated with faecal calcium excretion. Absolute calcium retention of infants given the sn2 palmitate formula was increased by more than $20 \mathrm{mg} / \mathrm{kg}$ daily.

Only one study has reported on the influence of the triacylglycerol structure on the absorption of fatty acids in term infants (Filer et al. 1969). In this early study, a formula based on natural lard (containing palmitic acid mainly at the sn-2 position) was compared with one based on randomized lard. The absorption of all fatty acids was improved in the infants receiving the formula containing natural lard, the effect being most pronounced for palmitic and stearic acids.

Palmitic acid is not the only fatty acid to show a specific preference for a particular position in human milk triacylglycerols; oleic acid and stearic acid are mainly located at the 
sn-1 position, whereas linoleic acid is located mainly in the sn- 1 and sn-3 positions. AA and DHA are found primarily esterified in the sn-2 $(\sim 50 \%)$ and sn-3 $(\sim 45 \%)$ positions of human milk (Martin et al. 1993).

Because human milk is the natural source of fat for the newborn, the structure of its triacylglycerols may be used as a reference point for the design of lipid sources for infant formulas. Thus, adaptation of the triacylglycerol structure of infant fat to approximate that of human milk more closely seems a logical step in the further improvement of infant formula. The triacylglycerol structure of infant formula lipids could be modified by the process of 1,3-enzymic interesterification or by chemical randomization (Lien et al. 1993; Quinlan \& Moore, 1993).

\section{CHOLESTEROL}

The widespread occurrence of atherosclerosis in developed countries has increased the emphasis on prevention of this disorder. One question that has been the subject of numerous studies is whether or not the infant's diet influences blood cholesterol or lipoprotein concentrations later in life. It is well documented that infants given human milk have higher plasma total cholesterol and plasma LDL cholesterol concentrations and a higher LDL:HDL cholesterol ratio than formula fed infants (Jooste et al. 1991; Kallio et al. 1992; Hayes et al. 1992). These differences, which gradually diminish at the age of one year, are primarily attributable to the relatively high cholesterol content, $100-150 \mathrm{mg} / \mathrm{l}$, of human milk (Clark \& Hundrieser, 1989; Lammi-Keefe et al. 1990), rather than to its relatively high level of saturated fatty acids (Carlson et al. 1982; Hayes et al. 1992). Wong et al. (1993) recently observed, using the ${ }^{2} \mathrm{H}_{2} \mathrm{O}$ method, that the 6-fold greater cholesterol intake of breast fed infants resulted in a 3-fold suppression of cholesterol synthesis compared with formula fed infants. This down-regulation of cholesterol synthesis did not prevent increases in plasma total cholesterol and LDL-cholesterol concentrations in the breast fed group.

Data from animal studies suggest that there may be long term effects of infant diet on cholesterol metabolism. Adult baboons that were breast fed during infancy have lower HDL cholesterol concentrations, higher LDL + VLDL:HDL cholesterol ratios, lower cholesterol production and bile acid excretion rates, more extensive arterial lesions and an increased bile cholesterol saturation index (which may promote gallstone formation) compared with those fed formula (Mott et al. 1990, 1991). Additionally, short term exposure to high dietary cholesterol in early life has been found to increase arterial sensitivity to further cholesterol insult in adult rabbits in terms of enhanced atherogenesis, despite normalization of plasma cholesterol in these animals (Subbiah et al. 1989).

The question of whether there are also long term effects of breast versus formula feeding on serum cholesterol concentrations in humans has not been solved. Among children of 2.5 years (Ward et al. 1980) and of 7-12 years of age (Hodgson et al. 1976), those that were breast fed had higher serum cholesterol levels than those fed formula. Other investigators studying children 1-8 years of age observed no differences in serum cholesterol concentrations related to breast $v$. formula feeding (Huttunen $e t$ al. 1983; Fomon $e t$ al. 1984; Jooste et al. 1991). Measurement of plasma total cholesterol alone, however, may not be sufficient to identify the effects of early postnatal cholesterol ingestion on cholesterol homeostasis later in life (Hamosh, 1988). Fall et al. (1992) recently presented data which showed that adult men born during 1911-30 who were either exclusively breast fed during the first year of life or exclusively bottle fed from birth had higher mortality ratios from ischaemic heart disease and higher serum total cholesterol and LDL cholesterol concentrations than men who were either both breast and bottle fed or breast fed but 
weaned before one year. No information was available on the fat composition of the bottle feeds, but it is to be expected that these formulas contained a high percentage of (cholesterol-rich) milk fat.

Cholesterol is not an essential nutrient; the human fetus is able to synthesize cholesterol endogenously from the 11th week of gestation and the cholesterol needed for brain myelinization is entirely synthesized within the brain (Carr \& Simpson, 1981; Edmond et al. 1991). However, as breast feeding is the natural method of feeding an infant, it has been postulated that the cholesterol level of human milk must be considered physiological, and it has been questioned whether infant formulas in this respect are sufficient at the moment (Kallio et al. 1992). The hypothesis that exogenous cholesterol may influence the biochemical composition and function of the small intestinal microvillus membrane could not be confirmed in a study in neonatal pigs (Engelhardt et al. 1991). Van Biervliet et al. (1992) reported that addition of cholesterol to formula affected maturation of the HDL particles and postulated that exogenous cholesterol may promote adequate delivery of cholesterol and AA to the developing brain. Others hypothesize that cholesterol is present in human milk merely because it is needed for the secretion of milk fat, and are not in favour of adding cholesterol to infant formulas as an increased LDL:HDL cholesterol ratio is associated with increased atherogenic risk in adults, and as expansion of the LDL pool may result in a decrease of the LCP-rich HDL pool by down-regulation of hepatic LDL receptors (Hayes et al. 1992).

A clear understanding of the role of cholesterol in human milk will depend on future research. Additional well controlled human studies are warranted to answer the question whether or not addition of cholesterol to infant formulas is desirable.

\section{CARBOHY DRATES}

Until now, the carbohydrate contribution of human milk has been attributed for the most part to the disaccharide lactose, generally neglecting the fact that human milk is a rich source of oligosaccharides. The latter are complex sugars composed of D-glucose, Dgalactose, L-fucose, $N$-acetylglucosamine, and $N$-acetylneuraminic acid (sialic acid). They may be classed either as acidic or neutral according to the presence or absence of sialic acid (Kunz \& Rudloff, 1993). Oligosaccharides are synthesized in the mammary gland by the action of several enzymes, which add specific monosaccharides to the core structure. Some of the fucosyloligosaccharides in human milk have structural similarity to blood group determinants of the mother (ABH secretor and Lewis secretor type), as a result of the activity of fucosyltransferases common to the two systems (Viverge et al. 1990).

More than 100 oligosaccharide structures in human milk have been characterized so far (Kunz \& Rudloff, 1993). Oligosaccharides represent about $27 \%$ of total carbohydrates in colostrum, decreasing to $19 \%$ by day 30 until a value of $15-16 \%$ is reached by day 60 (Coppa et al. 1991, 1993). The major oligosaccharide in human milk is lacto- $N$-tetraose (Gal $\beta 1-3 \mathrm{Glc} N A \mathrm{c} \beta 1-3 \mathrm{Gal} \beta 1-4 \mathrm{Glc}$ ), followed by monofucosylated lacto- $N$-fucopentaose I and II. These three carbohydrates add up to approximately $50-70 \%$ of the complex carbohydrates (Kunz \& Rudloff, 1993).

Sialyllactose is the only complex oligosaccharide present in both human milk and bovine milk (Parkkinen \& Finne, 1987; Neeser et al. 1991). Human milk sialyllactose consists primarily of the $(\alpha 2-6)$ isomer, whereas bovine sialyllactose is mainly in the ( $\alpha 2-3)$ form (Parkkinen \& Finne, 1987; Kunz \& Rudloff, 1993).

The pattern of urinary oligosaccharides in breast fed infants is strongly related to that of the milk they ingest, which might be explained by intestinal absorption of intact oligosaccharides from human milk (Coppa et al. 1990). 
It is well recognized that oligosaccharides containing $N$-acetylglucosamine stimulate the growth of Bifidobacterium species. Already in 1954, it was found that such oligosaccharides from human milk stimulated the growth of Bifidobacterium bifidum subsp. pennsylvanicus, which was originally isolated from the faeces of breast fed infants (Gauhe et al. 1954). However, this strain is exceptional in that it is unable to utilize glucose and requires Dglucosamine derivatives for cell wall synthesis (Veerkamp, 1969). $N$-acetylglucosamine appears not to promote the in vitro growth of $B$. infantis, B. breve and B. longum (Petschow \& Talbott, 1991).

As enteropathogens use the oligosaccharide portion of glycolipids and glycoproteins as targets for attachment of whole bacteria and toxins, human milk oligosaccharides might prevent intestinal attachment of microorganisms by acting as receptor analogues competing with intestinal ligands for binding. Neutral oligosaccharides from human colostrum caused inhibition of adhesion to uroepithelial cells of a strain of $E$. coli isolated from an infant with urinary tract infection (Coppa et al. 1990). Additionally, human milk oligosaccharides inhibited the adherence of Streptococcus pneumoniae to human pharyngeal or buccal epithelial cells, the inhibitory activity being in the same concentration range as that of synthetic lacto- $N$-tetraose and lacto- $N$-neotetraose (Andersson et al. 1986). In a similar way, fucose containing oligosaccharides from human milk could abolish the binding activity of Vibrio cholerae (Holmgren et al. 1983). Sialyl( $(22-3)$ lactose was found to inhibit haemagglutination of Campylobacter pylori and of S-fimbriae carrying strains of E. coli which may cause meningitis and neonatal sepsis in newborns (Korhonen et al. 1985; Evans et al. 1988), but its concentration in human milk may be too low to exert a significant inhibiting effect (Schroten et al. 1993).

Another possible function of human milk oligosaccharides is to provide the infant with sialic acid. Human milk contains about $1 \mathrm{~g} / \mathrm{l}$ of oligosaccharide derived sialic acid during the first week of lactation, a value which decreases to about $250 \mathrm{mg} / 1$ at $6-8$ weeks (Carlson, 1985b). Whey and casein predominant formulas have been reported to contain only $50-70$ and $10-30 \mathrm{mg} / 1$ of oligosaccharide derived sialic acid respectively (Carlson, 1985b; Neeser et al. 1991). It is known that mammalian species, including man, have the capacity to synthesize sialic acid from simple sugars and phosphoenolpyruvate. However, the relative capacity for synthesis by the neonate has not been studied (Carlson, 1985b). There is evidence from animal studies that exogenous administration of sialic acid can significantly increase its content in synaptosomal regions of the brain, and is associated with desirable early and long term modifications of behaviour (Morgan \& Winick, 1980, 1981).

More basic and clinical research is warranted to clarify outstanding questions regarding the possible functions and gastrointestinal metabolism of the various oligosaccharides. Assuming that human milk oligosaccharides indeed contribute to the wellbeing of the baby, it is to be foreseen that eventually infant formulas will be supplemented with oligosaccharides. However, it is as yet too early to decide which of the more than 100 human milk oligosaccharides would be the best candidates for supplementation and in which amounts these complex sugars should be added to infant formulas.

\section{MINERALS AND TRACE ELEMENTS}

\section{CALCIUM AND PHOSPHORUS}

Compared with cows' milk, human milk is very low in calcium and phosphorus. Values for mature milk range from $200-350$ and $110-160 \mathrm{mg} / 1$ for calcium and phosphorus respectively (Gross et al. 1980; Anderson, 1992). Although calcium and phosphorus levels of human milk are significantly lower than those of current infant formulas, bone 
mineralization is similar in breast and formula fed infants (Hillman et al. 1988; Mimouni et al. 1993).

The low phosphorus content of human milk is held to be advantageous to the infant for several reasons (Manz, 1992). Firstly, owing to the low phosphorus and protein content of human milk, its buffering capacity is poor; this is suggested as one of the factors responsible for the low $\mathrm{pH}$ and the characteristic bacterial flora of the intestine of breast fed infants (Bullen \& Willis, 1971; Balmer \& Wharton, 1989). Secondly, owing to the immature renal handling of phosphates in the newborn, high phosphorus intakes substantially increase serum phosphorus levels (Manz, 1992). Increased serum phosphorus and parathyroid levels, and decreased serum ionized calcium levels have been observed during the first week of age in infants receiving a formula with a high phosphorus content, regardless of its $\mathrm{Ca}: \mathrm{P}$ ratio (Specker et al. 1991). High serum phosphorus levels can have clinical consequences. Occasionally, hypocalcaemic tetany may occur in otherwise healthy term infants receiving a high phosphorus formula (Venkataraman et al. 1985). Finally, a high phosphorus intake is a risk factor for the development of metabolic acidosis in high risk term infants (Kalhoff et al. 1990).

It is not unlikely that in the future both calcium and phosphorus levels of infant formulas will be further reduced to levels closer to human milk, provided that mineral homeostasis and bone mineralization prove to be adequate. Calcium and phosphorus could be reduced to levels of around 400 and $200 \mathrm{mg} / 1$ respectively without negatively affecting bone mineralization of term infants (Vainsel, 1992).

\section{IRON}

Human milk has a very low iron content of about $0.5 \mathrm{mg} / 1$, yet term breast fed infants rarely exhaust their iron stores until after four months of age (Saarinen et al. 1977; Siimes et al. 1979; Calvo et al. 1992). This is attributed to the high absorption of iron from breast milk (Saarinen et al. 1977; Fomon et al. 1993). Iron absorption from infant formulas is significantly lower (Saarinen \& Siimes, 1977; Fomon et al. 1993), probably at least partly owing to their higher calcium content and the presence of bovine casein and whey proteins (Hurrell et al. 1989; Hallberg et al. 1992).

The optimal iron level in infant formulas is still a major controversy. The Committee on Nutrition of the American Academy of Pediatrics (1992) recommends that iron fortified formula be used for all formula fed infants during the first year of life. These formulas should contain between 1 and $2 \mathrm{mg}$ of iron per $100 \mathrm{kcal}$, or between 7 and $13 \mathrm{mg} / \mathrm{l}$ (Committee on Nutrition, American Academy of Pediatrics, 1976). Most iron fortified formulas available in the United States contain iron levels at the upper limit of this recommendation. Iron fortified formulas available in Europe generally contain lower amounts of iron, $5-8 \mathrm{mg} / \mathrm{l}$. These lower amounts have been found to be equally effective in supporting normal iron status (Bradley et al. 1993; Haschke et al. 1993). Even a formula with an iron content as low as $3 \mathrm{mg} / \mathrm{l}$ could prevent infants from developing iron deficiency during the first 6 months of life (Haschke et al. 1993).

Whether iron fortification of formula is preferable right from birth is uncertain. It can be argued that the body iron content at term birth of most infants is sufficient to support haematopoiesis until about 4 months of age (Dallman, 1986; Aggett et al. 1989). Another argument against the initial fortification of formula with iron is that omission of iron gives a faecal flora somewhat closer to breast milk (Mevissen-Verhage et al. 1985; Balmer \& Wharton, 1991). The impression that low iron formulas are associated with fewer gastrointestinal side effects is not supported by controlled studies (Oski, 1980; Nelson et al. 1988). 


\section{SELENIUM, MOLYBDENUM AND CHROMIUM}

Selenium functions as an integral cofactor for glutathione peroxidase (EC 1.11.1.9), which catalyses the destruction of peroxides, is part of the selenoprotein Type I iodothyronine deiodinase, and is a component of several other selenoproteins of which the metabolic functions are not yet understood (Rotruck et al. 1973; Arthur et al. 1993). At the present time, proper data on the selenium requirement of the infant are lacking; selenium intakes and status of the exclusively breast fed infant should therefore serve as the basis for recommendations on infant feeding. Selenium levels of mature human milk are in the range $12-20 \mu \mathrm{g} / \mathrm{l}$, whereas unfortified milk based formulas generally contain between 3 and $9 \mu \mathrm{g} / \mathrm{l}$ of intrinsic selenium (Roekens et al. 1985; Kumpulainen et al. 1987; Dörner et al. 1990). The higher selenium intake of the breast fed infant as well as the higher availability of human milk selenium are reflected in higher serum selenium concentrations and a higher selenium retention compared to formula fed infants (Kumpulainen $e t$ al. 1987; Dörner $e t$ al. 1990; McGuire et al. 1993).

It is to be expected that in the near future all infant formulas will be fortified with selenium to levels found in mature human milk. Supplementation of infant formulas with sodium selenite has been found to be effective in maintaining selenium status comparable to that observed in human milk fed infants (Kumpulainen et al. 1987; Litov et al. 1989; McGuire et al. 1993). American formula manufacturers have already started supplementing their infant formulas with sodium selenite. In Europe, addition of selenium has to await the formalization of the latest 1993 amendment to the EC Directive. Sodium selenite, selenate, selenomethionine, and selenium-enriched yeast, provided that the selenomethionine concentration of these yeasts is well standardized, will then be permitted for use in European infant formulas. The optimal form of selenium supplementation still requires further research. The potentially most promising candidate for organic selenium supplementation could be selenocysteine, the bioactive form of selenium found in glutathione peroxidase and other selenoproteins. Selenomethionine has the drawback that it is metabolized like methionine and therefore is non-specifically incorporated into a large number of proteins (Behne et al. 1991). Selenocysteine, on the other hand, is specifically inserted into glutathione peroxidase and other selenoproteins by a selenocysteine specific tRNA which differs from that for cysteine. Selenocysteine can therefore be seen as the 21st amino acid in terms of ribosome mediated protein synthesis (Böck et al. 1991).

As the chromium content of infant formulas $(5-25 \mu \mathrm{g} / \mathrm{l})$ is much higher than that of mature human milk $(0.2-0.5 \mu \mathrm{g} / \mathrm{l})$, the addition of chromium to infant formulas is not necessary (Deelstra et al. 1988; Foucault et al. 1989; Kumpulainen, 1992). The same holds true for molybdenum: levels found in infant formula and mature human milk are 15-200 and $1-3 \mu \mathrm{g} / 1$ respectively (Casey \& Neville, 1987; Bougle et al. 1988; Foucault et al. 1989).

\section{VITAMINS AND CONDITIONALLY ESSENTIAL SUBSTANCES}

The vitamin levels of infant formulas are based on the values found in mature human milk, corrected for losses during processing and storage.

\section{$\beta$-CAROTENE}

Human milk, particularly colostrum, contains considerable amounts of $\beta$-carotene. The concentration of $\beta$-carotene in human milk decreases from $2.13 \mathrm{mg} / 1$ at day 1 to $0.4 \mathrm{mg} / 1$ at day 5 of lactation. Owing to the high concentrations of $\beta$-carotene in colostrum and early breast milk, the serum level of $\beta$-carotene of breast fed infants increases rapidly during this 
period to normal adult levels, whereas it does not rise in formula fed infants (Ostrea et al. 1986).

It has recently been demonstrated in infants that $\beta$-carotene can be converted to retinal by an intestinal mucosal enzyme (Lakshman et al. 1993). Thus, $\beta$-carotene may serve as a source of vitamin $\mathrm{A}$ in the neonatal period. Additionally, $\beta$-carotene may provide the infant's defence against oxygen toxicity by quenching singlet oxygen and free radicals (Ostrea et al. 1986; Krinsky, 1988). Future research should better define the role of dietary $\beta$-carotene in protecting the infant against oxygen toxicity, as well as in enhancing immune function (Bendich, 1991).

\section{INOSITOL}

Inositol, a component of membrane phospholipids and of compounds involved in signal transduction, is present in mature human milk in an amount of $250-300 \mathrm{mg} / 1$ (Bromberger \& Hallman, 1986; Pereira et al. 1990). Serum inositol of preterm infants correlates significantly with inositol intake, the concentration being higher in infants receiving human milk than in those receiving unsupplemented formulas, which are low in inositol (Bromberger \& Hallman, 1986; Pereira et al. 1990). Recently, it was reported that inositol supplementation to preterm infants with respiratory distress syndrome during the first week of life was associated with increased survival, a lower incidence of bronchopulmonary dysplasia, and a lower incidence of retinopathy of prematurity (Hallman et al. 1992). The authors suggested that inositol may increase surfactant availability through increased synthesis, release or recycling. Varying amounts of inositol have already been added to some formulas. Future research should further evaluate the importance of dietary inositol during the neonatal period, especially among high risk preterm infants.

\section{TAURINE}

Taurine is now added to nearly all infant formulas, although the effects of taurine supplementation on cholesterol synthesis, bile acid excretion, fat and vitamin $\mathrm{D}$ absorption, and auditory brainstem evoked responses have been shown only in infants born preterm (Tyson et al. 1989; Wasserhess et al. 1993; Zamboni et al. 1993).

\section{NUCLEOTIDES}

The importance of dietary nucleotides in infant nutrition has been the subject of active research for the last decade. Human milk is known to contain a significant amount of nucleotides (Gil \& Sanchez-Medina, 1982; Janas \& Picciano, 1982). Nucleotide supplemented formulas have been available in Spain and Japan for a number of years, and have more recently been introduced in the United States of America.

The clinical evidence for the claimed beneficial effects of dietary nucleotides is yet far from convincing. The results of Gil et al. $(1986 a)$ who found that nucleotides enhanced the growth of bifidobacteria in the faecal flora of infants could not be confirmed in a very recent study of Balmer et al. (1994). In this last study, at 2 weeks of age the reverse effect was noted with more nucleotide supplemented infants colonized with $E$. coli and a reduction in the counts of bifidobacteria. Dietary nucleotides only marginally influenced the essential fatty acid status of infants (Gil et al. 1986 b; DeLucchi et al. 1987). Effects of dietary nucleotides on the gastrointestinal system and on hepatic growth and function have only been observed in animal studies (Uauy et al. 1990; Bustamante et al. 1994; Novak et al. 1994). Nucleotide supplementation appeared significantly to increase all plasma lipoprotein concentrations in preterm, but not in term infants (Sanchez-Pozo et al. 1994). A quite fascinating finding that 
warrants further study has been that dietary nucleotides increased indices of cell mediated immunity in infants without, however, influencing incidence and severity of infections (Carver et al. 1991). Very recently, it was reported that infants living in a contaminated environment, fed a nucleotide supplemented formula, experienced less diarrhoea than controls receiving an unsupplemented formula (Brunser et al. 1994). The only significant difference between the two groups, however, was the number of first episodes of diarrhoea. The total number of episodes of diarrhoea, the total duration of episodes, and the pattern of enteropathogens isolated did not differ between the supplemented infants and the controls. More clinical research needs to be done to determine efficacy, safety, and optimal level of supplementation, and to elucidate what population of infants will derive clear benefit from dietary nucleotides, before routine supplementation of infant formulas with nucleotides can be recommended (Quan \& Barness, 1990).

\section{CONCLUDING REMARKS}

Through the last decades, infant formulas have been developed that closely approach human milk in nutrient composition. As knowledge has accumulated about the effects and action of different substances in human milk which serve other than nutritional roles, some of them have already been incorporated into infant formulas. Whether all nutritional and metabolic components of human milk confer unequivocal benefit to the infant in terms of growth and development is difficult to determine. For many substances, such as hormones and hormone binding proteins, vitamin binding proteins, growth factors, enzymes, and various non-protein nitrogen components, it will be extremely difficult to demonstrate clear functional advantages of supplementation, while the costs of addition of these substances will generally be substantial. Therefore, attempts to improve the composition of infant formulas should be applauded, but the benefits of compositional modifications should be carefully weighed against the costs. Unlike the rigid USA guidelines, it is to be hoped that the European guidelines for clinical testing of infant formulas, which are currently being drawn up, will provide a reasonable balance between protecting public health against opportunistic supplementations and leaving room for scientific innovations.

Obviously, no formula can supplant mother's milk as the ideal food for healthy term infants. The biological properties of human milk make it uniquely suited to the human infant. In the years to come, researchers will continue to attempt to identify and explain the role of different substances in human milk in the hope of incorporating all the benefits provided by human milk into infant formulas. It will be a major challenge for the industry to concentrate efforts on those substances which have a clear physiological function and thus are worth their price.

\section{REFERENCES}

Aggett, P. J., Barclay, S. \& Whitley, J. E. (1989). Iron for the suckling. Acta Paediatrica Scandinavica Suppl. 361, 96-102.

Anderson, R. R. (1992). Variations in major minerals of human milk during the first 5 months of lactation. Nutrition Research 12, 701-711.

Andersson, B., Porras, O., Hanson, L. A., Lagergård, T. \& Svanborg-Edén, C. (1986). Inhibition of attachment of Streptococcus pneumoniae and Haemophilus influenzae by human milk and receptor oligosaccharides. Journal of Infectious Diseases 153, 232-237.

Arthur, J. R., Nicol, F. \& Beckett, G. J. (1993). Selenium deficiency, thyroid hormone metabolism, and thyroid hormone deiodinases. American Journal of Clinical Nutrition 57, S236-\$239.

Atkinson, S. A., Schnurr, C. M., Donovan, S. M. \& Lönnerdal, B. (1989). The non-protein nitrogen components in human milk: biochemistry and potential functional role. In Protein and Non-protein Nitrogen in Human Milk, pp. 117-133 [S. A. Atkinson and B. Lönnerdal, editors]. Boca Raton, FL: CRC Press.

Balmer, S. E., Hanvey, L. S. \& Wharton, B. A. (1994). Diet and faecal flora in the newborn: nucleotides. Archives of Disease in Childhood 70, F137-F140. 
Balmer, S. E., Scott, P. H. \& Wharton, B. A. (1989). Diet and faecal flora in the newborn: casein and whey proteins. Archives of Disease in Childhood 64, 1678-1684.

Balmer, S. E. \& Wharton, B. A. (1989). Diet and faecal flora in the newborn: breast milk and infant formula. Archives of Disease in Childhood 64, 1672-1677.

Balmer, S. E. \& Wharton, B. A. (1991). Diet and faecal flora in the newborn: iron. Archives of Disease in Childhood 66, 1390-1394.

Bauchner, H., Leventhal, J. M. \& Shapiro, E. D. (1986). Studies of breast-feeding and infections. How good is the evidence? Journal of the American Medical Association 256, 887-892.

Behne, D., Kyriakopoulos, A., Scheid, S. \& Gessner, H. (1991). Effects of chemical form and dosage on the incorporation of selenium into tissue proteins in rats. Journal of Nutrition 121, 806-814.

Bellamy, W., Takase, M., Yamauchi, K., Wakabayashi, H., Kawase, K. \& Tomita, M. (1992). Identification of the bactericidal domain of lactoferrin. Biochimica et Biophysica Acta 1121, 130-136.

Bendich, A. (1991). $\beta$-Carotene and the immune response. Proceedings of the Nutrition Society 50, $263-274$.

Bernbäck, S., Bläckberg, L. \& Hernell, O. (1990). The complete digestion of human milk triacylglycerol in vitro requires gastric lipase, pancreatic colipase-dependent lipase, and bile salt-stimulated lipase. Journal of Clinical Investigation 85, 1221-1226.

Billeaud, C., Guillet, J. \& Sandler, B. (1990). Gastric emptying in infants with or without gastro-oesophageal reflux according to the type of milk. European Journal of Clinical Nutrition 44, 577-583.

Birch, E. E., Birch, D. G., Hoffman, D. R., Hale, L., Everett, M. \& Uauy, R. (1993). Breast-feeding and optimal visual development. Journal of Pediatric Ophthalmology and Strabismus 30, 33-38.

Birch, E. E., Birch, D. G., Hoffman, D. R. \& Uauy, R. (1992). Dietary essential fatty acid supply and visual acuity development. Investigative Ophthalmology and Visual Science 33, 3242-3253.

Böck, A., Forchhammer, K., Heider, J., Leinfelder, W., Sawers, G., Veprek, B. \& Zinoni, F. (1991). Selenocysteine: the 21st amino acid. Molecular Microbiology 5, 515-520.

Boesman-Finkelstein, M. \& Finkelstein, R. A. (1991). Bovine lactogenic immunity against pediatric enteropathogens. In Immunology of Milk and the Neonate, pp. 361-367 [J. Mestecky, C. Blair and P. L. Ogra, editors]. New York: Plenum Press.

Bougle, D., Bureau, F., Foucault, P., Duhamel, J.-F., Muller, G. \& Drosdowsky, M. (1988). Molybdenum content of term and preterm human milk during the first 2 months of lactation. American Journal of Clinical Nutrition 48, 652-654.

Bradley, C. K., Hillman, L., Sherman, A. R., Leedy, D. \& Cordano, A. (1993). Evaluation of two iron-fortified, milk-based formulas during infancy. Pediatrics 91, 908-914.

British Nutrition Foundation. (1992). Unsaturated Fatty Acids. Nutritional and Physiological Significance. London: Chapman \& Hall.

Bromberger, P. \& Hallman, M. (1986). Myoinositol in small preterm infants: relationship between intake and serum concentration. Journal of Pediatric Gastroenterology and Nutrition 5, 455-458.

Brooke, O. G. (1985). Absorption of lard by infants. Human Nutrition: Applied Nutrition 39A, $221-223$.

Brunser, O., Espinoza, J., Araya, M., Cruchet, S. \& Gil, A. (1994). Effect of dietary nucleotide supplementation on diarrhoeal disease in infants. Acta Paediatrica 83, 188-191.

Brunser, O., Espinoza, J., Figueroa, G., Araya, M., Spencer, E., Hilpert, H., Link-Amster, H. \& Brussow, H. (1992). Field trial of an infant formula containing anti-rotavirus and anti-Escherichia coli milk antibodies from hyperimmunized cows. Journal of Pediatric Gastroenterology and Nutrition 15, 63-72.

Bullen, C. L. \& Willis, A. T. (1971). Resistance of the breast-fed infant to gastroenteritis. British Medical Journal iii, $338-343$.

Bustamante, S. A., Sanches, N., Crosier, J., Miranda, D., Colombo, G. \& Miller, M. J. S. (1994). Dietary nucleotides: effects on the gastrointestinal system in swine. Journal of Nutrition 124, 149S-156S.

Butte, N. F., Wong, W. W., Ferlic, L., O'Brian Smith, E., Klein, P. D. \& Garza, C. (1990). Energy expenditure and deposition of breast-fed and formula-fed infants during early infancy. Pediatric Research $28,631-640$.

Calvo, E. B., Galindo, A. C. \& Aspres, N. B. (1992). Iron status in exclusively breast-fed infants. Pediatrics 90 , 375-379.

Carlson, S. E. (1985a). Human milk nonprotein nitrogen: occurrence and possible functions. Advances in Pediatrics 32, 43-70.

Carlson, S. E. (1985b). $N$-Acetylneuraminic acid concentrations in human milk oligosaccharides and glycoproteins during lactation. American Journal of Clinical Nutrition 41, 720-726.

Carlson, S. E., Cooke, R. J., Rhodes, P. G., Peeples, J. M., Werkman, S. H. \& Tolley, E. A. (1991). Long-term feeding of formulas high in linolenic acid and marine oil to very low birth weight infants: phospholipid fatty acids. Pediatric Research 30, 404-412.

Carlson, S. E., Cooke, R. J., Werkman, S. H. \& Tolley, E. A. (1992b). First year growth of preterm infants fed standard compared to marine oil n-3 supplemented formula. Lipids 27, 901-907.

Carlson, S. E., De Voe, P. W. \& Barness, L. A. (1982). Effect of infant diets with different polyunsaturated to saturated fat ratios on circulating high-density lipoproteins. Journal of Pediatric Gastroenterology and Nutrition 1, 303-309.

Carlson, S. E., Werkman, S. H., Peeples, J. M., Cooke, R. J. \& Tolley, E. A. (1993a). Arachidonic acid status correlates with first year growth in preterm infants. Proceedings of the National Academy of Sciences, USA $\mathbf{9 0}$, 1073-1077. 
Carlson, S. E., Werkman, S. H., Peeples, J. M., Cooke, R. J. \& Wilson, W. W. (1992a). Plasma phospholipid arachidonic acid and growth and development of preterm infants. In Recent Advances in Infant Feeding, pp. 22-27 [B. Koletzko, A. Okken, J. Rey, B. Salle and J. P. Van Biervliet, editors]. Stuttgart: Thieme.

Carlson, S. E., Werkman, S. H., Rhodes, P. G. \& Tolley, E. A. (1993b). Visual-acuity development in healthy preterm infants: effect of marine-oil supplementation. American Journal of Clinical Nutrition 58, 35-42.

Carnielli, V. P., Luijendijk, I. H. T., van Goudoever, J. B., Sulkers, E. J., Boerlage, A., Degenhart, H. J. \& Sauer, J. J. (1994). Feeding premature newborn infants palmitic acid in amounts and stereo isomeric position similar to human milk: effects on fat and mineral balance. American Journal of Clinical Nutrition (submitted).

Carr, B. R. \& Simpson, E. R. (1981). Synthesis of cholesterol in the human fetus: 3-hydroxy-3-methylglutaryl coenzyme A reductase activity of liver microsomes. Journal of Clinical Endocrinology and Metabolism 53, $810-812$.

Carver, J. D., Pimentel, B., Cox, W. I. \& Barness, L. A. (1991). Dietary nucleotide effects upon immune function in infants. Pediatrics 88, 359-363.

Casey, C. E. \& Neville, M. C. (1987). Studies in human lactation. 3. Molybdenum and nickel in human milk during the first month of lactation. American Journal of Clinical Nutrition 45, 921-926.

Chierici, R., Sawatzki, G., Tamisari, L., Volpato, S. \& Vigi, V. (1992). Supplementation of an adapted formula with bovine lactoferrin. 2. Effects on serum iron, ferritin and zinc levels. Acta Paediatrica 81, 475-479.

Christie, W. W. (1986). The positional distributions of fatty acids in triglycerides. In Analysis of Oils and Fats, pp. 313-340 [R. J. Hamilton, J. B. Rossell \& D. Reffold, editors]. London: Elsevier.

Chung, T. D. Y. \& Raymond, K. N. (1993). Lactoferrin: the role of conformational changes in its iron binding and release. Journal of the American Chemical Society 115, 6765-6768.

Clandinin, M. T., Chappell, J. E., Leong, S., Heim, T., Swyer, P. R. \& Chance, G. W. (1980a). Intrauterine fatty acid accretion rates in infant brain: implications for fatty acid requirements. Early Human Development 4 , $121-129$.

Clandinin, M. T., Chappell, J. E., Leong, S., Heim, T., Swyer, P. R. \& Chance, G. W. (1980b). Extrauterine fatty acid accretion rates in infant brain; implications for fatty acid requirements. Early Human Development 4 , 131-138.

Clark, K. J., Makrides, M., Neumann, M. A. \& Gibson, R. A. (1992). Determination of the optimal ratio of linoleic acid to $\alpha$-linolenic acid in infant formulas. Journal of Pediatrics 120, S151-S158.

Clark, R. M. \& Hundrieser, K. E. (1989). Changes in cholesteryl esters of human milk with total milk lipid. Journal of Pediatric Gastroenterology and Nutrition 9, 347-350.

Cockburn, F. (1994). Neonatal brain and dietary lipids. Archives of Disease in Childhood 70, F1-F2.

Committee on Nutrition, American Academy of Pediatrics. (1976). Commentary on breast-feeding and infant formulas, including proposed standards for formulas. Pediatrics 57, 278-285.

Committee on Nutrition, American Academy of Pediatrics. (1992). The use of whole cow's milk in infancy. Pediatrics 89, 1105-1109.

Coppa, G. V., Gabrielli, O., Giorgi, P., Catassi, C., Montanari, M. P., Varaldo, P. E. \& Nichols, B. L. (1990). Preliminary study of breastfeeding and bacterial adhesion to uroepithelial cells. Lancet 335, 569-571.

Coppa, G. V., Gabrielli, O., Pierani, P., Catassi, C., Carlucci, A. \& Giorgi, P. L. (1993). Changes in carbohydrate composition in human milk over 4 months of lactation. Pediatrics 91, 637-641.

Coppa, G. V., Gabrielli, O., Pierani, P., Zampini, L., Rottoli, G., Carlucci, A. \& Giorgi, P. L. (1991). [Qualitative and quantitative studies of carbohydrates of human colostrum and mature milk.] Rivista Italiana di Pediatria 17, 303-307.

Dallman, P. R. (1986). Iron deficiency in the weanling: a nutritional problem on the way to resolution. Acta Paediatrica Scandinavica Suppl. 323, 59-67.

Daniel, H., Vohwinkel, M. \& Rehner, G. (1990). Effect of casein and $\beta$-casomorphins on gastrointestinal motility in rats. Journal of Nutrition 120, 252-257.

Davidson, G. P., Whyte, P. B. D., Daniels, E., Franklin, K., Nunan, H., McCloud, P. I., Moore, A. G. \& Moore, D. J. (1989). Passive immunisation of children with bovine colostrum containing antibodies to human rotavirus. Lancet ii, 709-712.

Davidson, L.-A. \& Lönnerdal, B. (1987). Persistence of human milk proteins in the breastfed infant. Acta Paediatrica Scandinavica 76, 733-740.

Davidsson, L., Kastenmayer, P., Yuen, M., Lönnerdal, B. \& Hurrell, R. F. (1994). Influence of lactoferrin on iron absorption from human milk in infants. Pediatric Research 35, 117-124.

Davin, J.-C., Senterre, J. \& Mahieu, P. R. (1991). The high lectin-binding capacity of human secretory IgA protects nonspecifically mucosae against environmental antigens. Biology of the Neonate 59, 121-125.

Deelstra, H., Van Schoor, O., Robberecht, H., Clara, R. \& Eylenbosch, W. (1988). Daily chromium intake by infants in Belgium. Acta Paediatrica Scandinavica 77, 402-407.

DeLucchi, C., Pita, M. L., Faus, M. J., Molina, J. A., Uauy, R. \& Gil, A. (1987). Effects of dietary nucleotides on the fatty acid composition of erythrocyte membrane lipids in term infants. Journal of Pediatric Gastroenterology and Nutrition 6, 568-574.

Department of Health and Social Security (1977). The Composition of Mature Human Milk (Reports on Health and Social Subjects no. 12). London: HMSO.

Donovan, S. M. \& Lönnerdal, B. (1989). Non-protein nitrogen and true protein in infant formulas. Acta Paediatrica Scandinavica 78, 497-504. 
Dörner, K., Schneider, K., Sievers, E., Schulz-Lell, G., Oldigs, H.-D. \& Schaub, J. (1990). Selenium balances in young infants fed on breast milk and adapted cow's milk formula. Journal of Trace Elements and Electrolytes in Health and Disease 4, 37-40.

Ebina, T., Sato, A., Umezu, K., Ishida, N., Ohyama, S., Oizumi, A., Aikawa, K., Katagiri, S., Katsushima, N., Imai, A., Kitaoka, S., Suzuki, H. \& Konno, T. (1985). Prevention of rotavirus infection by oral administration of cow colostrum containing antihumanrotavirus antibody. Medical Microbiology and Immunology 174, $177-185$.

Edmond, J., Korsak, R. A., Morrow, J. W., Torok-Both, G. \& Catlin, D. H. (1991). Dietary cholesterol and the origin of cholesterol in the brain of developing rats. Journal of Nutrition 121, 1323-1330.

Eigel, W. N., Butler, J E., Ernstrom, C. A., Farrell, H. M., Harwalkar, V. R., Jenness, R. \& Whitney, R. McL. (1984). Nomenclature of proteins of cow's milk: fifth revision. Journal of Dairy Science 67, 1599-1631.

Engelhardt, E. L., Sankar, M., Wu-Wang, C. Y., Thomas, M. R., Walker, W. R. \& Neu, J. (1991). Effect of cholesterol deprivation on piglet small intestinal and serum lipids. Journal of Pediatric Gastroenterology and Nutrition 12, 494-500.

ESPGAN Committee on Nutrition. (1982). Guidelines on infant nutrition. III. Recommendations for infant feeding. Acta Paediatrica Scandinavica Suppl. 302, 1-27.

ESPGAN Committee on Nutrition. (1991). Comment on the content and composition of lipids in infant formulas. Acta Paediatrica Scandinavica 80, 887-896.

Evans, D. G., Evans, D. J., Moulds, J. J. \& Graham, D. Y. (1988). N-acetylneuraminyllactose-binding fibrillar hemagglutinin of Campylobacter pylori: a putative colonization factor antigen. Infection and Immunity 56, 2896-2906.

Facon, M., Skura, B. J. \& Nakai, S. (1993). Potential for immunological supplementation of foods. Food and Agricultural Immunology 5, 85-91.

Fairweather-Tait, S. J., Balmer, S. E., Scott, P. H. \& Minski, M. J. (1987). Lactoferrin and iron absorption in newborn infants. Pediatric Research 22, 651-654.

Fall, C. H. D., Barker, D. J. P., Osmond, C., Winter, P. D., Clark, P. M. S. \& Hales, C. N. (1992). Relation of infant feeding to adult serum cholesterol concentration and death from ischaemic heart disease. British Medical Journal 304, 801-805.

Farquharson, J., Cockburn, F., Patrick, W. A., Jamieson, E. C. \& Logan, R. W. (1992). Infant cerebral cortex phospholipid fatty-acid composition and diet. Lancet 340, 810-813.

Farquharson, J., Cockburn, F., Patrick, W. A., Jamieson, E. C. \& Logan, R. W. (1993). Effect of diet on infant subcutaneous tissue triglyceride fatty acids. Archives of Disease in Childhood 69, 589-593.

Fazzolari-Nesci, A., Domianello, D., Sotera, V. \& Räihä, N. C. R. (1992). Tryptophan fortification of adapted formula increases plasma tryptophan concentrations to levels not different from those found in breast-fed infants. Journal of Pediatric Gastroenterology and Nutrition 14, 456-459.

Filer, L. J., Mattson, F. H. \& Fomon, S. J. (1969). Triglyceride configuration and fat absorption by the human infant. Journal of Nutrition 99, 293-298.

Fomon, S. J., Bier, D. M., Matthews, D. E., Rogers, R. R., Edwards, B. B., Ziegler, E. E. \& Nelson, S. E. (1988). Bioavailability of dietary urea nitrogen in the breast-fed infant. Journal of Pediatrics 113, 515-517.

Fomon, S. J., Rogers, R. R., Ziegler, E. E., Nelson, S. E. \& Thomas, L. N. (1984). Indices of fatness and serum cholesterol at age eight years in relation to feeding and growth during early infancy. Pediatric Research 18 , $1233-1238$.

Fomon, S. J., Ziegler, E. E. \& Nelson, S. E. (1993). Erythrocyte incorporation of ingested ${ }^{58}$ Fe by 56 -day-old breast-fed and formula-fed infants. Pediatric Research 33, 573-576.

Foreman-van Drongelen, M. M. H. P., van Houwelingen, A. C., Kester, A. D. M., de Jong, A. E. P., Blanco, C. E., Hasaart, T. H. M. \& Hornstra, G. (1994). Long chain polyene status of preterm infants with regard to the fatty acid composition of their diet : comparison between absolute and relative fatty acid amounts in plasma and red blood cell phospholipids. British Journal of Nutrition (in press).

Foucault, P., Bureau, F., Bougle, D., Neuville, D., Duhamel, J. F. \& Drosdowsky, M. (1989). [Trace elements in 26 infant formulas.] Cahiers de Nutrition et de Diététique 24, 385-388.

Freeman, C. P., Jack, E. L. \& Smith, L. M. (1965). Intramolecular fatty acid distribution in the milk fat triglycerides of several species. Journal of Dairy Science 48, 853-858.

Gauhe, A., György, P., Hoover, J. R. E., Kuhn, R., Rose, C. S., Ruelius, H. W. \& Zilliken, F. (1954). Bifidus factor. IV. Preparations obtained from human milk. Archives of Biochemistry and Biophysics 48, $214-224$.

Gil, A., Corral, E., Martinez, A. \& Molina, J. A. (1986 a). Effects of the addition of nucleotides to an adapted milk formula on the microbial pattern of faeces in at term newborn infants. Journal of Clinical Nutrition and Gastroenterology 1, 127-132.

Gil, A., Pita, M., Martinez, A., Molina, J. A. \& Sanchez Medina, F. (1986 b). Effect of dietary nucleotides on the plasma fatty acids in at-term neonates. Human Nutrition: Clinical Nutrition 40C, 185-195.

Gil, A. \& Sanchez-Medina, F. (1982). Acid-soluble nucleotides of human milk at different stages of lactation. Journal of Dairy Research 49, 301-307.

Goldman, A. S. (1989). Immunologic supplementation of cow's milk formulations. International Dairy Federation Bulletin no. 244, 38-43.

Goldman, A. S., Garza, C., Nichols, B. L. \& Goldblum, R. M. (1982). Immunologic factors in human milk during the first year of lactation. Journal of Pediatrics 100, 563-567. 
Goldman, A. S. \& Goldblum, R. M. (1989). Immunoglobulins in human milk. In Protein and Non-protein Nitrogen in Human Milk, pp. 43-51 [S. A. Atkinson and B. Lönnerdal, editors]. Boca Raton, FL: CRC Press.

Gross, S. J., David, R. J., Bauman, L. \& Tomarelli, R. M. (1980). Nutritional composition of milk produced by mothers delivering preterm. Journal of Pediatrics 96, 641-644.

Hallberg, L., Rossander-Hulten, L., Brune, M. \& Gleerup, A. (1992). Bioavailability in man of iron in human milk and cow's milk in relation to their calcium contents. Pediatric Research 31, 524-527.

Hallman, M., Bry, K., Hoppu, K., Lappi, M. \& Pohjavuori, M. (1992). Inositol supplementation in premature infants with respiratory distress syndrome. New England Journal of Medicine 326, 1233-1239.

Hambraeus, L., Lönnerdal, B., Forsum, E. \& Gebre-Medhin, M. (1978). Nitrogen and protein components of human milk. Acta Paediatrica Scandinavica 67, 561-565.

Hamosh, M. (1988). Does infant nutrition affect adiposity and cholesterol levels in the adult? Journal of Pediatric Gastroenterology and Nutrition 7, 10-16.

Hanning, R. M., Paes, B. \& Atkinson, S. A. (1992). Protein metabolism and growth of term infants in response to a reduced-protein 40:60. whey: casein formula with added tryptophan. American Journal of Clinical Nutrition 56, 1004-1011.

Hanson, L. А., Ashraf, R., Zaman, S., Karlberg, J., Lindblad, B. S. \& Jalil, F. (1994). Breast feeding is a natural contraceptive and prevents disease and death in infants, linking infant mortality and birth rates. Acta Paediatrica 83, 3-6.

Harrison, G. G., Graver, E. J., Vargas, M., Churella, H. R. \& Paule, C. L. (1987). Growth and adiposity of term infants fed whey-predominant or casein-predominant formulas or human milk. Journal of Pediatric Gastroenterology and Nutrition 6, 739-747.

Harzer, G. \& Bindels, J. G. (1985). Changes in human milk immunoglobulin A and lactoferrin during early lactation. In Composition and Physiological Properties of Human Milk, pp. 285-293 [J. Schaub, editor]. Amsterdam: Elsevier Science Publishers.

Harzer, G., Haug, M. \& Bindels, J. G. (1986). Biochemistry of maternal milk in early lactation. Human Nutrition: Applied Nutrition 40A, Suppl. 1, 11-18.

Haschke, F., Vanura, H., Male, C., Owen, G., Pietschnig, B., Schuster, E., Krobath, E. \& Huemer, C. (1993). Iron nutrition and growth of breast- and formula-fed infants during the first 9 months of life. Journal of Pediatric Gastroenterology and Nutrition 16, 151-156.

Hayes, K. C., Pronczuk, A., Wood, R. A. \& Guy, D. G. (1992). Modulation of infant formula fat profile alters the low-density lipoprotein/high-density lipoprotein ratio and plasma fatty acid distribution relative to those with breast-feeding. Journal of Pediatrics 120, S109-S116.

Heine, W., Tiess, M. \& Wutzke, K. D. (1986). ${ }^{15} \mathrm{~N}$-tracer investigations of the physiological availability of urea nitrogen in mother's milk. Acta Paediatrica Scandinavica 75, 439-443.

Heinig, M. J., Nommsen, L. A., Peerson, J. M., Lönnerdal, B. \& Dewey, K. G. (1993). Energy and protein intakes of breast-fed and formula-fed infants during the first year of life and their association with growth velocity: the DARLING study. American Journal of Clinical Nutrition 58, 152-161.

Hillman, L. S., Chow, W., Salmons, S. S., Weaver, E., Erickson, M. \& Hansen, J. (1988). Vitamin D metabolism, mineral homeostasis, and bone mineralization in term infants fed human milk, cow milk-based formula, or soybased formula. Journal of Pediatrics 112, 864-874.

Hodgson, P. A., Ellefson, R. D., Elveback, L. R., Harris, L. E., Nelson, R. A. \& Weidman, W. H. (1976). Comparison of serum cholesterol in children fed high, moderate, or low cholesterol milk diets during neonatal period. Metabolism 25, 739-746.

Holmgren, J., Svennerholm, A.-M. \& Lindblad, M. (1983). Receptor-like glycocompounds in human milk that inhibit classical and El Tor Vibrio cholerae cell adherence (hemagglutination). Infection and Immunity 39, $147-154$.

Howie, P. W., Forsyth, J. S., Ogston, S. A., Clark, A. \& Florey, C. du V. (1990). Protective effect of breast feeding against infection. British Medical Journal 300, 11-16.

Hurrell, R. F., Lynch, S. R., Trinidad, T. P., Dassenko, S. A. \& Cook, J. D. (1989). Iron absorption in humans as infuenced by bovine milk proteins. American Journal of Clinical Nutrition 49, 546-552.

Huttunen, J. K., Saarinen, U. M., Kostiainen, E. \& Siimes, M. A. (1983). Fat composition of the infant diet does not influence subsequent serum lipid levels in man. Atherosclerosis 46, 87-94.

Iyer, S. \& Lönnerdal, B. (1993). Lactoferrin, lactoferrin receptors and iron metabolism. European Journal of Clinical Nutrition 47, 232-241.

Janas, L. M. \& Picciano, M. F. (1982). The nucleotide profile of human milk. Pediatric Research 16, $659-662$.

Janas, L. M., Picciano, M. F. \& Hatch, T. F. (1985). Indices of protein metabolism in term infants fed human milk, whey-predominant formula, or cow's milk formula. Pediatrics 75, 775-784.

Janas, L. M., Picciano, M. F. \& Hatch, T. F. (1987). Indices of protein metabolism in term infants fed either human milk or formulas with reduced protein concentration and various whey/casein ratios. Journal of Pediatrics 110, 838-848.

Järvenpää, A. L., Räihä, N. C. R., Rassin, D. K. \& Gaull, G. E. (1982a). Milk protein quantity and quality in the term infant. I. Metabolic responses and effects on growth. Pediatrics 70, 214-220.

Järvenpää, A. L., Räihä, N. C. R., Rassin, D. K. \& Gaull, G. E. (1982b). Milk protein quantity and quality in the term infant. II. Effects on acidic and neutral amino acids. Pediatrics 70, 221-230. 
Jason, J. M., Nieburg, P. \& Marks, J. S. (1984). Mortality and infectious disease associated with infant-feeding practices in developing countries. Pediatrics 74, 702-727.

Jooste, P. L., Rossouw, L. J., Steenkamp, H. J., Rossouw, J. E., Swanepoel, A. S. P. \& Charlton, D. O. (1991). Effect of breast feeding on the plasma cholesterol and growth of infants. Journal of Pediatric Gastroenterology and Nutrition 13, 139-142.

Kalhoff, H., Manz, F., Diekmann, L. \& Stock, G. J. (1990). Suboptimal mineral composition of cow's milk formulas: a risk factor for the development of late metabolic acidosis. Acta Paediatrica Scandinavica 79, 743-749.

Kallio, M. J. T., Salmenperä, L., Siimes, M. A., Perheentupa, J. \& Miettinen, T. A. (1992). Exclusive breastfeeding and weaning: effect on serum cholesterol and lipoprotein concentrations in infants during the first year of life. Pediatrics 89, 663-666.

Kidwell, W. R. \& Salomon, D. S. (1989). Growth factors in human milk: sources and potential physiological roles. In Protein and Non-protein Nitrogen in Human Milk, pp. 117-133 [S. A. Atkinson and B. Lönnerdal, editors]. Boca Raton, FL: CRC Press.

Koletzko, B., Thiel, I. \& Abiodun, P. O. (1992). The fatty acid composition of human milk in Europe and Africa. Journal of Pediatrics 120, S62-S70.

Korhonen, T. K., Valtonen, M. V., Parkkinen, J., Väisänen-Rhen, V., Finne, J., Ørskov, F., Ørskov, I., Svenson, S. B. \& Mäkelä, P. H. (1985). Serotypes, hemolysin production, and receptor recognition of Escherichia coli strains associated with neonatal sepsis and meningitis. Infection and Immunity 48, 486-491.

Krimpenfort, P. (1993). The production of human lactoferrin in the milk of transgenic animals. Cancer Detection and Prevention 17, 301-305.

Krinsky, N. I. (1988). The evidence for the role of carotenoids in preventive health. Clinical Nutrition 7, $107-112$.

Kuhn, D. C. \& Crawford, M. (1986). Placental essential fatty acid transport and prostaglandin synthesis. Progress in Lipid Research 25, 345-353.

Kumpulainen, J. T. (1992). Chromium content of foods and diets. Biological Trace Element Research 32, 9-18.

Kumpulainen, J., Salmenperä, L., Siimes, M. A., Koivistoinen, P., Lehto, J. \& Perheentupa, J. (1987). Formula feeding results in lower selenium status than breast-feeding or selenium supplemented formula feeding: a longitudinal study. American Journal of Clinical Nutrition 45, 49-53.

Kunz, C. \& Lönnerdal, B. (1990). Casein and casein subunits in preterm milk, colostrum, and mature human milk. Journal of Pediatric Gastroenterology and Nutrition 10, $454-461$.

Kunz, C. \& Lönnerdal, B. (1992). Re-evaluation of the whey protein/casein ratio of human milk. Acta Paediatrica 81, 107-112.

Kunz, C. \& Rudlofi, S. (1993). Biological functions of oligosaccharides in human milk. Acta Paediatrica 82 , 903-912.

Lakshman, M. R., Johnson, L. H., Okoh, C., Attlesey, M., Mychkovsky, I. \& Bhagavan, H. N. (1993). Conversion of all trans $\beta$-carotene to retinal by an enzyme from the intestinal mucosa of human neonates. Journal of Nutritional Biochemistry 4, 659-663.

Lammi-Keefe, C. J., Ferris, A. M. \& Jensen, R. G. (1990). Changes in human milk at 06.00, 10.00, 18.00 and 22.00 h. Journal of Pediatric Gastroenterology and Nutrition 11, 83-88.

Li-Chan, E. \& Nakai, S. (1989). Enzymic dephosphorylation of bovine casein to improve acid clotting properties and digestibility for infant formula. Journal of Dairy Research 56, 381-390.

Lien, E. L., Yuhas, R. J., Boyle, F. G. \& Tomarelli, R. M. (1993). Corandomization of fats improves absorption in rats. Journal of Nutrition 123, 1859-1867.

Litov, R. E., Sickles, V. S., Chan, G. M., Hargett, I. R. \& Cordano, A. (1989). Selenium status in term infants fed human milk or infant formula with or without added selenium. Nutrition Research 9, 585-596.

Lönnerdal, B. \& Chen, C.-L. (1990). Effects of formula protein level and ratio on infant growth, plasma amino acids and serum trace elements. 1. Cow's milk formula. Acta Paediatrica Scandinavica 79, 257-265.

Lucas, A., Davies, P. S. W. \& Phil, M. (1990). Physiologic energy content of human milk. In Breastfeeding, Nutrition, Infection and Infant Growth in Developed and Emerging Countries, pp. 337-357 [S. A. Atkinson, L. A. Hanson and R. K. Chandra, editors]. Newfoundland: ARTS Biomedical Publishers and Distributors.

McGuire, M. K., Burgert, S. L., Milner, J. A., Glass, L., Kummer, R., Deering, R., Boucek, R. \& Picciano, M. F. (1993). Selenium status of infants is influenced by supplementation of formula or maternal diets. American Journal of Clinical Nutrition 58, 643-648.

Makrides, M., Neumann, M. A., Simmer, K. \& Gibson, R. A. (1993a). Dietary supply of polyunsaturated fats and neural function of infants. XII National Conference of the Dieticians Association of Australia. Abstract.

Makrides, M., Simmer, K., Goggin, M. \& Gibson, R. A. (1993b). Erythrocyte docosahexaenoic acid correlates with the visual response of healthy, term infants. Pediatric Research 33, 425-427.

Manz, F. (1992). Why is the phosphorus content of human milk exceptionally low? Monatsschrift für Kinderheilkunde 140, Suppl. 1, S35-S39.

Martin, J.-C., Bougnoux, P., Antoine, J.-M., Lanson, M. \& Couet, C. (1993). Triacylglycerol structure of human colostrum and mature milk. Lipids 28, 637-643.

Mevissen-Verhage, E. A. E., Marcelis, J. H., Harmsen-Van Amerongen, W. C. M., de Vos, N. M., Berkel, J. \& Verhoef, J. (1985). Effect of iron on neonatal gut flora during the first week of life. European Journal of Clinical Microbiology 4, 14-19. 
Migliore-Samour, D. \& Jollès, P. (1988). Casein, a prohormone with an immunomodulating role for the newborn? Experientia 44, 188-193.

Mimouni, F., Campaigne, B., Neylan, M. \& Tsang, R. C. (1993). Bone mineralization in the first year of life in infants fed human milk, cow-milk formula, or soy-based formula. Journal of Pediatrics 122, 348-354.

Morgan, B. L. G. \& Winick, M. (1980). Effects of administration of $N$-acetylneuraminic acid (NANA) on brain NANA content and behavior. Journal of Nutrition 110, 416-424.

Morgan, B. L. G. \& Winick, M. (1981). The subcellular localization of administered $N$-acetylneuraminic acid in the brains of well-fed and protein restricted rats. British Journal of Nutrition 46, 231-238.

Mott, G. E., Jackson, E. M. \& McMahan, C. A. (1991). Bile composition of adult baboons is influenced by breast versus formula feeding. Journal of Pediatric Gastroenterology and Nutrition 12, 121-126.

Mott, G. E., Jackson, E. M., McMahan, C. A. \& McGill, H. C. (1990). Cholesterol metabolism in adult baboons is influenced by infant diet. Journal of Nutrition 120, 243-251.

Nakai, S. \& Li-Chan, E. (1987). Effect of clotting in stomachs of infants on protein digestibility of milk. Food Microstructure 6, 161-170.

Neeser, J.-R., Golliard, M. \& Del Vedovo, S. (1991). Quantitative determination of complex carbohydrates in bovine milk and in milk-based infant formulas. Journal of Dairy Science 74, 2860-2871.

Nelson, S. E., Ziegler, E. E., Copeland, A. M., Edwards, B. B. \& Fomon, S. J. (1988). Lack of adverse reactions to iron-fortified formula. Pediatrics 81, 360-364.

Nichols, B. L., McKee, K. S., Henry, J. F. \& Putman, M. (1987). Human lactoferrin stimulates thymidine incorporation into DNA of rat crypt cells. Pediatric Research 21, 563-567.

Novak, D. A., Carver, J. D. \& Barness, L. A. (1994). Dietary nucleotides affect hepatic growth and composition in the weanling mouse. Journal of Parenteral and Enteral Nutrition 18, 62-66.

Oski, F. A. (1980). Iron-fortified formulas and gastrointestinal symptoms in infants: a controlled study. Pediatrics 66, 168-170.

Ostrea, E. M., Balun, J. E., Winkler, R. \& Porter, T. (1986). Influence of breast-feeding on the restoration of the low serum concentration of vitamin $\mathrm{E}$ and $\beta$-carotene in the newborn infant. American Journal of Obstetrics and Gynecology 154, $1014-1017$.

Parkkinen, J. \& Finne, J. (1987). Isolation of sialyl oligosaccharides and sialyl oligosaccharide phosphates from bovine colostrum and human urine. Methods in Enzymology 138, 289-300.

Pegg, A. E. (1986). Recent advances in the biochemistry of polyamines in eukaryotes. Biochemical Journal 234, 249-262.

Pereira, G. R., Baker, L., Egler, J., Corcoran, L. \& Chiavacci, R. (1990). Serum myoinositol concentrations in premature infants fed human milk, formula for infants, and parenteral nutrition. American Journal of Clinical Nutrition 51, 589-593.

Petschow, B. W. \& Talbott, R. D. (1991). Response of bifidobacterium species to growth promotors in human and cow milk. Pediatric Research 29, 208-213.

Picone, T. A., Benson, J. D., Moro, G., Minoli, I., Fulconis, F., Rassin, D. K. \& Räihä, N. C. R. (1989). Growth, serum biochemistries, and amino acids of term infants fed formulas with amino acid and protein concentrations similar to human milk. Journal of Pediatric Gastroenterology and Nutrition 9, 351-360.

Pollack, P. F., Koldovskỳ, O. \& Nishioka, K. (1992). Polyamines in human and rat milk and in infant formulas. American Journal of Clinical Nutrition 56, 371-375.

Prentice, A. M., Lucas, A., Vasquez-Velasquez, L., Davies, P. S. W. \& Whitehead, R. G. (1988). Are current dietary guidelines for young children a prescription for overfeeding? Lancet ii, 1066-1069.

Quan, R. \& Barness, L. A. (1990). Do infants need nucleotide supplemented formula for optimal nutrition? Journal of Pediatric Gastroenterology and Nutrition 11, 429-434.

Quinlan, P. \& Moore, S. (1993). Modification of triglycerides by lipases: process technology and its application to the production of nutritionally improved fats. Inform 4, 580-585.

Räihä, N. C. R. (1985). Nutritional proteins in milk and the protein requirement of normal infants. Pediatrics 75 , S136-SI41.

Räihä, N., Minoli, I. \& Moro, G. (1986a). Milk protein intake in the term infant. I. Metabolic responses and effects on growth. Acta Paediatrica Scandinavica 75, 881--886.

Räihä, N., Minoli, I., Moro, G. \& Bremer, H. J. (1986b). Milk protein intake in the term infant. II. Effects on plasma amino acid concentrations. Acta Paediatrica Scandinavica 75, 887-892.

Roekens, E., Robberecht, H., Van Caillie-Bertrand, M., Deelstra, H. \& Clara, R. (1985). Daily intake of selenium by bottle-fed infants in Belgium. European Journal of Pediatrics 144, 45-48.

Romain, N., Dandrifosse, G., Jeusette, F. \& Forget, P. (1992). Polyamine concentration in rat milk and food, human milk, and infant formulas. Pediatric Research 32, 58-63.

Rönneberg, R. \& Skåra, B. (1992). Essential fatty acids in human colostrum. Acta Paediatrica 81, 779-783.

Rotruck, J. T., Pope, A. L., Ganther, H. E., Swanson, A. B., Hafeman, D. G. \& Hoekstra, W. G. (1973). Selenium: biochemical role as a component of glutathione peroxidase. Science 179, 588-590.

Rubin, D. H., Leventhal, J. M., Krasilnikoff, P. A., Kuo, H. S., Jekel, J. F., Weile, B., Levee, A., Kurzon, M. \& Berget, A. (1990). Relationship between infant feeding and infectious illness: a prospective study of infants during the first year of life. Pediatrics 85, 464-471.

Saarinen, U. M. \& Siimes, M. A. (1977). Iron absorption from infant milk formula and the optimal level of iron supplementation. Acta Paediatrica Scandinavica 66, 719-722. 
Saarinen, U. M., Siimes, M. A. \& Dallman, P. R. (1977). Iron absorption in infants: high bioavailability of breast milk iron as indicated by the extrinsic tag method of iron absorption and by the concentration of serum ferritin. Journal of Pediatrics 91, 36-39.

Saito, H., Miyakawa, H., Tamura, Y., Shimamura, S. \& Tomita, M. (1991). Potent bactericidal activity of bovine lactoferrin hydrolysate produced by heat treatment at acidic pH. Journal of Dairy Science 74, 3724-3730.

Sanchez-Pozo, A., Morillas, J., Molto, L., Robles, R. \& Gil, A. (1994). Dietary nucleotides influence lipoprotein metabolism in newborn infants. Pediatric Research 35, 112-116.

Schroten, H., Plogmann, R., Hanisch, F. G., Hacker, J., Nobis-Bosch, R. \& Wahn, V. (1993). Inhibition of adhesion of S-fimbriated $E$. coli to buccal epithelial cells by human skim milk is predominantly mediated by mucins and depends on the period of lactation. Acta Paediatrica 82, 6-11.

Schulz-Lell, G., Dörner, K., Oldigs, H. D., Sievers, E. \& Schaub, J. (1991). Iron availability from an infant formula supplemented with bovine lactoferrin. Acta Paediatrica Scandinavica 80, 155-158.

Shield, J., Meville, C., Novelli, V., Anderson, G., Scheimberg, I., Gibb, D. \& Milla, P. (1993). Bovine colostrum immunoglobulin concentrate for cryptosporidiosis in AIDS. Archives of Disease in Childhood 69, 451-453.

Siimes, M. A., Vuori, E. \& Kuitunen, P. (1979). Breast milk iron: a declining concentration during the course of lactation. Acta Paediatrica Scandinavica 68, 29-31.

Small, D. M. (1991). The effects of glyceride structure on absorption and metabolism. Annual Review of Nutrition 11, $413-434$.

Specker, B. L., Tsang, R. C., Ho, M. L., Landi, T. M. \& Gratton, T. L. (1991). Low serum calcium and high parathyroid hormone levels in neonates fed 'humanized' cow's milk-based formula. American Journal of Diseases of Children 145, 941-945.

Steinberg, L. A., O'Connell, N. C., Hatch, T. F., Picciano, M. F. \& Birch, L. L. (1992). Tryptophan intake influences infants' sleep latency. Journal of Nutrition 122, 1781-1791.

Subbiah, M. T. R., Sprinkle, J. D., Rymaszewski, Z. \& Yunker, R. L. (1989). Short-term exposure to high dietary cholesterol in early life: arterial changes and response after normalization of plasma cholesterol. American Journal of Clinical Nutrition 50, 68-72.

Tomarelli, R. M., Meyer, B. J., Weaber, J. R. \& Bernhart, F. W. (1968). Effect of positional distribution on the absorption of the fatty acids of human milk and infant formulas. Journal of Nutrition 95, 583-590.

Turner, R. B. \& Kelsey, D. K. (1991). Passive immunization for prevention of rotavirus infection. Pediatric Research 29, 187A.

Tyson, J. E., Lasky, R., Flood, D., Mize, C., Picone, T. \& Paule, C. L. (1989). Randomized trial of taurine supplementation for infants $\leqslant 1,300$-gram birth weight: effect on auditory brainstem-evoked responses. Pediatrics 83, $406-415$.

Uauy, R., Birch, E., Birch, D. \& Peirano, P. (1992). Visual and brain function measurements in studies of n-3 fatty acid requirements of infants. Journal of Pediatrics 120, S168-S180.

Uauy, R., Stringel, G., Thomas, R. \& Quan, R. (1990). Effect of dietary nucleosides on growth and maturation of the developing gut in the rat. Journal of Pediatric Gastroenterology and Nutrition 10, 497-503.

Vainsel, M. (1992). Evaluation of a low-phosphate cow's milk diet on growth and bone mineralization of full-term infants. Monatsschrift für Kinderheilkunde 140, Suppl. 1, S45-S50.

Van Biervliet, J.-P., Vinaimont, N., Vercaemst, R. \& Rosseneu, M. (1992). Serum cholesterol, cholesteryl ester, and high-density lipoprotein development in newborn infants: response to formulas supplemented with cholesterol and $\gamma$-linolenic acid. Journal of Pediatrics 120 (4), S101-S108.

Veerkamp, J. H. (1969). Uptake and metabolism of derivatives of 2-deoxy-2-amino-D-glucose in Bifidobacterium bifidum var. pennsylvanicus. Archives of Biochemistry and Biophysics 129, 248-256.

Venkataraman, P. S., Tsang, R. C., Greer, F. R., Noguchi, A., Laskarzewski, P. \& Steichen, J. J. (1985). Late infantile tetany and secondary hyperparathyroidism in infants fed humanized cow milk formula. American Journal of Diseases of Children 139, 664-668.

Verkade, H. J., van Asselt, W. A., Vonk, R. J., Bijleveld, C. M. A., Fernandes, J., de Jong, H., Fidler, V. \& Okken, A. (1989). Fat absorption in premature infants: the effect of lard and antibiotics. European Journal of Pediatrics 149, 126-129.

Viverge, D., Grimmonprez, L., Cassanas, G., Bardet, L. \& Solere, M. (1990). Discriminant carbohydrate components of human milk according to donor secretor types. Journal of Pediatric Gastroenterology and Nutrition 11, 365-370.

Ward, S. D., Melin, J. R., Lloyd, F. P., Norton, J. A. \& Christian, J. C. (1980). Determinants of plasma cholesterol in children - a family study. American Journal of Clinical Nutrition 33, 63-70.

Wasserhess, P., Becker, M. \& Staab, D. (1983). Effect of taurine on synthesis of neutral and acidic sterols and fat absorption in preterm and full-term infants. American Journal of Clinical Nutrition 58, 349-353.

Wong, W. W., Hachey, D. L., Insull, W., Opekun, A. R. \& Klein, P. D. (1993). Effect of dietary cholesterol on cholesterol synthesis in breast-fed and formula-fed infants. Journal of Lipid Research 34, 1403-1411.

Wright, A. L., Holberg, C. J., Martinez, F. D., Morgan, W. J., Taussig, L. M. \& Group Health Medical Associates. (1989). Breast feeding and lower respiratory tract illness in the first year of life. British Medical Journal 299, 946-949.

Zamboni, G., Piemonte, G., Bolner, A., Antoniazzi, F., Dall'Agnola, A., Messner, H., Gambaro, G. \& Tato, L. (1993). Influence of dietary taurine on vitamin D absorption. Acta Paediatrica 82, 811-815. 